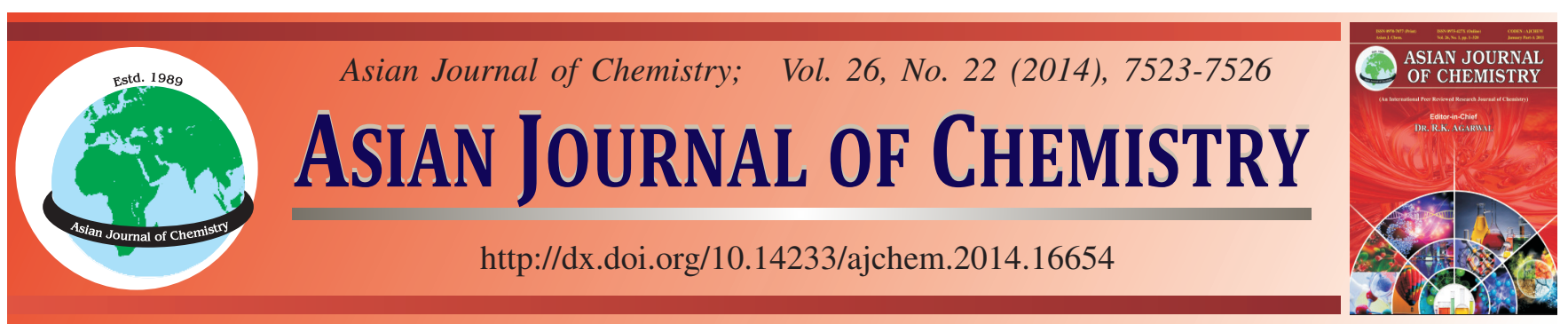

\title{
Synthesis, Crystal Structure and Antioxidation Study of Cadmium(II) Complex with bis( $N$-Methylbenzimidazol-2-ylmethyl)aniline
}

Yanhui Zhang, Furong Shi, Yuchen Bai, Xiaoli Wang, Chengyong Chen, Jiawen Zhang and Huilu Wu*

School of Chemical and Biological Engineering, Lanzhou Jiaotong University, Lanzhou 730070, P.R. China

*Corresponding author: E-mail: wuhuilu@163.com

Received: 8 November 2013;

Accepted: 25 February 2014;

Published online: 6 November 2014;

AJC-16177

\begin{abstract}
A complex of cadmium(II) picrate (pic) with bis( $N$-methylbenzimidazol-2-ylmethyl)aniline (Mebba), with composition $\left[\mathrm{Cd}(\mathrm{Mebba})_{2}\right](\text { pic })_{2}$, was synthesized and characterized by elemental analysis, electrical conductivity, IR and UV/visible spectral measurements. The crystal structure of the cadmium(II) complex has been determined by single-crystal X-ray diffraction. The Cd(II) cation is bonded to two Mebba ligands through four benzimidazole nitrogen atoms and two aniline nitrogen atoms, resulting in a distorted octahedral geometry. The ligand Mebba and $\mathrm{Cd}(\mathrm{II})$ complexes have scavenging effects for hydroxyl radicals and complex shows stronger scavenging effects for hydroxyl radicals.
\end{abstract}

Keywords: Bis( $N$-methylbenzimidazol-2-ylmethyl)aniline, Cadmium(II) complex, Crystal structure.

\section{INTRODUCTION}

Since the benzimidazole unit is the key building block for a variety of compounds which have crucial roles in the functions of biologically important molecules, there is a constant and growing interest over the past few years for the synthesis and biological studies of benzimidazole derivatives ${ }^{1-3}$. Benzimidazole compounds are environmentally friendly compounds with two high active nitrogen atoms in 1,3-sites ${ }^{4-6}$. Benzimidazoles and their derivatives have a wide range of biological activities such as anticancer ${ }^{7-10}$, antimicrobial ${ }^{11-12}$, antifungal $^{13}$, antiviral ${ }^{14}$, etc. An interesting concept for finding a complex with distinct biological and pharmaceutical features, the $\operatorname{bis}(N$-methylbenzimidazol-2-ylmethyl)aniline (Mebba) was selected as a ligand to chelate cadmium(II). In this paper, we report the synthesis, crystal structure and hydroxyl radical scavenging activity of the $\mathrm{Cd}(\mathrm{II})$ picrate complex with bis $(N$ methylbenzimidazol-2-ylmethyl)aniline.

\section{EXPERIMENTAL}

The $\mathrm{C}, \mathrm{H}$ and $\mathrm{N}$ elemental analyses were carried out using a Carlo Erba 1106 elemental analyzer. Electrolytic conductance measurements were made with a DDS-11A-type conductivity bridge using a $10^{-3} \mathrm{~mol} \mathrm{~L}^{-1}$ solution in DMF at room temperature. The IR spectra were recorded in the $4000-400 \mathrm{~cm}^{-1}$ region with a Nicolet FT-Vertex 70 spectrometer using $\mathrm{KBr}$ pellets. Electronic spectra were taken on a Lab-Tech UV Bluestar spectrophotometer. The fluorescence spectra were recorded on a LS-45 spectrofluorophotometer. ${ }^{1} \mathrm{H}$ NMR spectra were obtained with a Mercury plus $400 \mathrm{MHz}$ NMR spectrometer with TMS as internal standard and DMSO- $d_{6}$ as solvent. The antioxidant activity was performed in DMF solution with a 722-SP spectrophotometer.

Synthesis of bis(benzimidazol-2-ylmethyl)aniline(bba): bis(Benzimidazol-2-ylmethylene)aniline was synthesized following the procedure ${ }^{15}$. Yield: $67.08 \mathrm{~g}(75.8 \%)$. Anal. calcd. for $\mathrm{C}_{22} \mathrm{H}_{19} \mathrm{~N}_{5}(\%)$ : C, 74.77; H, 5.42; N, 19.82. Found (\%): C, 74.79; H, 5.41; N, 19.83. Selected IR data $\left(\mathrm{KBr}, v_{\max }, \mathrm{cm}^{-1}\right)$ : $1600(\mathrm{C}=\mathrm{C}), 1445(\mathrm{C}=\mathrm{N}), 1272(\mathrm{C}-\mathrm{N}), 743(\mathrm{O}-\mathrm{Ar}) .{ }^{1} \mathrm{H}$ NMR (400 MHz, DMSO- $\left.d_{6}\right)$ : 7.2 - 7.68 (m, 10H, benzimidazole), $6.55-7.10(\mathrm{~m}, 5 \mathrm{H}, \mathrm{Ph}), 5.14\left(\mathrm{~s}, 4 \mathrm{H}, \mathrm{CH}_{2}\right) . \Lambda_{\mathrm{M}}(\mathrm{DMF}, 297 \mathrm{~K})$ : $2.69 \mathrm{~S} \mathrm{~cm}^{2} \mathrm{~mol}^{-1}$. UV/visible (DMF): $\lambda=282 \mathrm{~nm}$.

Synthesis of bis ( $N$-methylbenzimidazol-2-ylmethyl) aniline (Mebba): The synthesis of the ligand Mebba is display as (Scheme-I). $5.3 \mathrm{~g}(0.015 \mathrm{~mol})$ bis(benzimidazol-2-ylmethylene $)$ aniline with $1.17 \mathrm{~g}(0.03 \mathrm{~mol})$ potassium in $150 \mathrm{~mL}$ evaporated tetrahydrofuran was followed by adding $4.26 \mathrm{~g}(0.03$ mol) iodomethane. The resulting solution was concentrated and recrystallized from methanol which was given pale yellow block crystals of Mebba. Yield: $4.34 \mathrm{~g}$ (75.8 \%). Anal. calcd. for $\mathrm{C}_{24} \mathrm{H}_{23} \mathrm{~N}_{5}(\%)$ : C, 75.56; H, 6.08; N, 18.36. Found (\%): C, 75.58; $\mathrm{H}, 6.07 ; \mathrm{N}, 18.37$. Selected IR data $\left(\mathrm{KBr}, \mathrm{v}_{\max }, \mathrm{cm}^{-1}\right): 1600(\mathrm{C}=\mathrm{C})$, $1447(\mathrm{C}=\mathrm{N}), 1280(\mathrm{C}-\mathrm{N}), 744$ (O-Ar). ${ }^{1} \mathrm{H}$ NMR $(400 \mathrm{MHz}$, DMSO- $\left.d_{6}\right): 7.13$ - 7.60 (m, 8H, benzimidazole), 7.09 - $6.64(\mathrm{~m}$, 5H, Ph), 5.019 (s, 4H, CH ), 3.78 (s, 6H, $\mathrm{CH}_{3}$ ). $\Lambda_{\mathrm{M}}(\mathrm{DMF}, 297$ $\mathrm{K}): 7.33 \mathrm{~S} \mathrm{~cm}^{2} \mathrm{~mol}^{-1}$. UV/visible (DMF): $\lambda=284 \mathrm{~nm}$. 


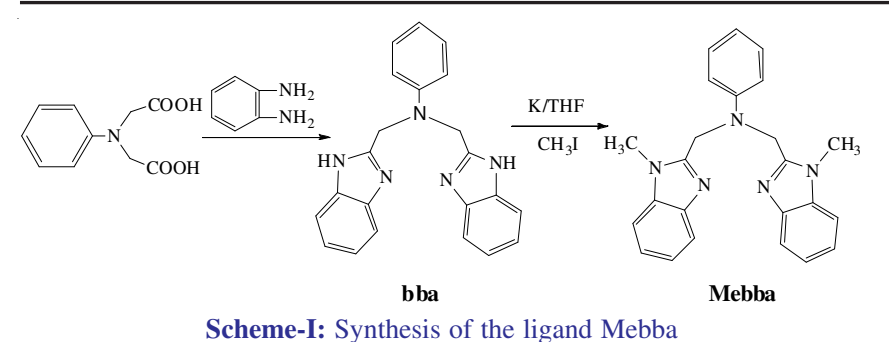

Preparation of $\left[\mathbf{C d}(\mathbf{M e b b a})_{2}\right](\text { pic })_{2}$ : To a stirred solution of Mebba (0.142 g, $0.5 \mathrm{mmol})$ in hot $\mathrm{MeOH}(10 \mathrm{~mL})$ was added $\mathrm{Cd}(\text { pic })_{2}(0.103 \mathrm{~g}, 0.25 \mathrm{mmol})$ in $\mathrm{MeOH}(5 \mathrm{~mL})$. A pale-yellow crystalline product formed rapidly. The precipitate was filtered off, washed with $\mathrm{MeOH}$ and absolute $\mathrm{Et}_{2} \mathrm{O}$ and dried in vacuo. The dried precipitate was dissolved in DMF to form a yellow solution into which $\mathrm{Et}_{2} \mathrm{O}$ was allowed to diffuse in at r.t. Pale yellow crystals of $\left[\mathrm{Cd}(\mathrm{Mebba})_{2}\right](\text { pic })_{2}$ suitable for X-ray diffraction were obtained after 5 days. Yield $0.4 \mathrm{~g}$ (59.7\%). Anal. calcd. for $\mathrm{C}_{60} \mathrm{H}_{50} \mathrm{~N}_{16} \mathrm{O}_{14} \mathrm{Cd}(\%)$ : C, 54.12; $\mathrm{H}$, 3.78; N, 16.83; Cd, 8.44. Found: C, 54.13; H, 3.79; N, 16.61; $\mathrm{Cd}$, 8.53. Selected IR data $\left(\mathrm{KBr}, v_{\max }, \mathrm{cm}^{-1}\right): 1633(\mathrm{C}=\mathrm{C}), 1495$ $(\mathrm{C}=\mathrm{N}), 1312(\mathrm{C}-\mathrm{N}), 742(\mathrm{O}-\mathrm{Ar}) . \Lambda_{\mathrm{M}}(\mathrm{DMF}, 297 \mathrm{~K}): 110.9 \mathrm{~S}$ $\mathrm{cm}^{2} \mathrm{~mol}^{-1}$. UV/visible (DMF): $\lambda=279,386 \mathrm{~nm}$.

$\mathrm{X}$-ray structure determination: All data were obtained using a Bruker Smart CCD diffractometer with graphite monochromated $\mathrm{MoK}_{\alpha}$ radiation $(\lambda=0.71073 \AA)$ at $296 \mathrm{~K}$. Date reduction and cell refinement were performed using SAINT programs ${ }^{16}$. The absorption corrections were carried out by the empirical method. The structure was solved by direct methods and refined by full-matrix least-squares against F2 of data using SHELXTL software ${ }^{17}$. The non-H atoms in the structure were subjected to anisotropic refinement. Hydrogen were located geometrically and treated with the riding model. Basic crystal data, description of the diffraction experiment and details of the structure refinement are given in Table- 1 . Selected bond distances and angles are presented in Table-2.

Crystallographic data for the $\mathrm{Cd}(\mathrm{II})$ complex has been deposited with the Cambridge Crystallographic Data Center as supplementary publication No. CCDC 826515. Copies of the data can be obtained free of charge on application to The Director, CCDC, 12 Union Road, Cambridge CB2 1EZ, UK (Fax: +44 1223336 033; E-mail: deposit@ccdc.cam.ac.uk).

\section{RESULTS AND DISCUSSION}

The Cd(II) comple $\left[\mathrm{Cd}(\mathrm{Mebba})_{2}\right](\text { pic })_{2}$ was prepared by reaction of Mebba with $\mathrm{Cd}(\mathrm{pic})_{2}$ in methanol. It is soluble in polar aprotic solvents such as DMF, DMSO and MeCN, slightly soluble in ethanol, methanol, ethyl acetate, chloroform and water. The elemental analysis shows that its composition is $\left[\mathrm{Cd}(\mathrm{Mebba})_{2}\right](\mathrm{pic})_{2}$, which was confirmed by the crystal structure analysis. The molar conductivities in DMF solution indicate that the $\mathrm{Cd}(\mathrm{II})$ complex is a $1: 2$ electrolyte compound ${ }^{18}$.

Crystal structure of $\left[\mathbf{C d}(\mathrm{Mebba})_{2}\right](\text { pic })_{2}$ : The central $\mathrm{Cd}(\mathrm{II})$ is six-coordinate, by virtue of six nitrogen atoms from two tridentate Mebba (Fig. 1). The coordination geometry of the $\mathrm{Cd}$ (II) may be best described as distorted octahedral with four benzimidazole coordination nitrogen atoms (N9, N13, $\mathrm{N} 14, \mathrm{~N} 16)$ from an equatorial plane. The equatorial distance

\begin{tabular}{cc} 
TABLE-1 \\
CRYSTAL DATA AND STRUCTURE \\
REFINEMENT FOR [Cd(Mebba) $\left.)_{2}\right](\mathrm{pic})_{2}$ \\
\hline Molecular formula & $\mathrm{C}_{60} \mathrm{H}_{50} \mathrm{~N}_{16} \mathrm{O}_{14} \mathrm{Cd}$ \\
Molecular weight ${ }^{1}$ & 1331.59 \\
Temperature $(\mathrm{K})$ & $293(2)$ \\
Crystal system & Monoclinic \\
Space group & $\mathrm{P} 21 / \mathrm{c}$ \\
Unit cell dimensions $\left(\AA{ }^{\circ}{ }^{\circ}\right)$ & $11.531(2)$ \\
$\mathrm{a}$ & $24.156(5)$ \\
$\mathrm{b}$ & $21.691(4)$ \\
$\alpha$ & 90 \\
$\beta$ & $102.21(3)$ \\
$\gamma$ & 90 \\
Volume $\left(\AA^{3}\right), \mathrm{Z}$ & $5905(2), 4$ \\
Calculated density $\left(\mathrm{g}\right.$ cm $\left.{ }^{3}\right)$ & 1.498 \\
$\mathrm{~F}(000)$ & 2728 \\
Crystal size $\left(\mathrm{mm}^{3}\right)$ & $0.31 \times 0.30 \times 0.29$ \\
$\theta$ Range for data collection $\left({ }^{\circ}\right)$ & $3.00-27.47$ \\
Reflections collected & 54883 \\
Independent reflection & $13425[\mathrm{R}(\mathrm{int})=0.0504]$ \\
Refinement method & Full-matrix least-squares \\
& on $\mathrm{F}^{2}$ \\
Data/restraints/parameters & $13425 / 0 / 844$ \\
Goodness-of-fit on $\mathrm{F}^{2}$ & 1.064 \\
Final $R$ indicies $[\mathrm{I}>2 \sigma(\mathrm{I})]$ & $\mathrm{R}_{1}=0.0376, \mathrm{wR} \mathrm{R}_{2}=0.0900$ \\
$\mathrm{R}$ indices $(\mathrm{all}$ data) & $0.0560, \mathrm{wR} 2=0.1042$ \\
Largest differences peak and hole $\left(\mathrm{e} \AA^{3}\right)$ & 0.505 and -0.699 \\
\hline
\end{tabular}

\begin{tabular}{|cccc}
\hline \multicolumn{5}{c}{ TABLE-2 } \\
\multicolumn{5}{c}{ BELECTED BOND LENGTHS $(\AA)$ AND Bth $(\AA)$} \\
\hline \multicolumn{4}{c}{ BOND ANGLES $\left(^{\circ}\right)$} \\
\hline $\mathrm{Cd}(1)-\mathrm{N}(9)$ & $2.2401(19)$ & $\mathrm{Cd}(1)-\mathrm{N}(16)$ \\
$\mathrm{Cd}(1)-\mathrm{N}(11)$ & $2.7309(18)$ & $\mathrm{Cd}(1)-\mathrm{N}(8)$ & $2.305(2)$ \\
$\mathrm{Cd}(1)-\mathrm{N}(14)$ & $2.759(2)$ & $\mathrm{Cd}(1)-\mathrm{N}(13)$ & $2.2681(19)$ \\
\multicolumn{4}{c}{ Bond angle $\left(^{\circ}\right)$} \\
\hline $\mathrm{N}(9)-\mathrm{Cd}(1)-\mathrm{N}(8)$ & $101.18(7)$ & $\mathrm{N}(9)-\mathrm{Cd}(1)-\mathrm{N}(13)$ & $109.46(7)$ \\
$\mathrm{N}(8)-\mathrm{Cd}(1)-\mathrm{N}(13)$ & $101.90(7)$ & $\mathrm{N}(9)-\mathrm{Cd}(1)-\mathrm{N}(16)$ & $96.12(8)$ \\
$\mathrm{N}(8)-\mathrm{Cd}(1)-\mathrm{N}(16)$ & $102.97(7)$ & $\mathrm{N}(13)-\mathrm{Cd}(1)-\mathrm{N}(16)$ & $139.75(8)$ \\
$\mathrm{N}(9)-\mathrm{Cd}(1)-\mathrm{N}(11)$ & $70.00(6)$ & $\mathrm{N}(8)-\mathrm{Cd}(1)-\mathrm{N}(11)$ & $162.19(7)$ \\
$\mathrm{N}(13)-\mathrm{Cd}(1)-\mathrm{N}(11)$ & $68.28(6)$ & $\mathrm{N}(16)-\mathrm{Cd}(1)-\mathrm{N}(11)$ & $93.53(6)$ \\
$\mathrm{N}(9)-\mathrm{Cd}(1)-\mathrm{N}(14)$ & $158.00(6)$ & $\mathrm{N}(8)-\mathrm{Cd}(1)-\mathrm{N}(14)$ & $70.17(7)$ \\
$\mathrm{N}(13)-\mathrm{Cd}(1)-\mathrm{N}(14)$ & $92.31(6)$ & $\mathrm{N}(16)-\mathrm{Cd}(1)-\mathrm{N}(14)$ & $67.49(6)$ \\
$\mathrm{N}(11)-\mathrm{Cd}(1)-\mathrm{N}(14)$ & $123.48(6)$ \\
\hline
\end{tabular}

for $\mathrm{N}(9), \mathrm{N}(13), \mathrm{N}(14)$ and $\mathrm{N}(16)$ nitrogens with metal ion are 2.2401 (19), 2.2680 (19), 2.759 (2) $\AA$ and 2.305 (2) $\AA$, respectively, where the largest deviation from the mean plane is $0.502 \AA$. The axial Cd-N (8) and Cd-N (11) distances are 2.2641 (19) and 2.7309 (18) $\AA$, respectively. The maximum angle deviations from ideal octahedral geometry are displayed by $\mathrm{N}(8)-\mathrm{Cd}(1)-\mathrm{N}(11), \mathrm{N}(13)-\mathrm{Cd}(1)-\mathrm{N}$ (16) and $\mathrm{N}(9)-\mathrm{Cd}$ (1)-N (14), with deviations of $17.81,49.75$ and $68^{\circ}$, respectively $^{19-22}$. Therefore, compared with a regular octahedron, it reflects a relatively distorted coordination octahedron around Cd(II).

IR and UV spctra: The IR spectral data for the free ligand and the $\mathrm{Cd}(\mathrm{II})$ complex with their relative assignments have been studied to characterize their structures. The IR spectrum of the free ligand Mebba shows characteristic absorption bands of the benzimidazole group at 1600, 1447 and $1280 \mathrm{~cm}^{-1}$ assigned to $v(C=C), v(C=N)$ and $v(C-N)$, respectively ${ }^{23,24}$. 


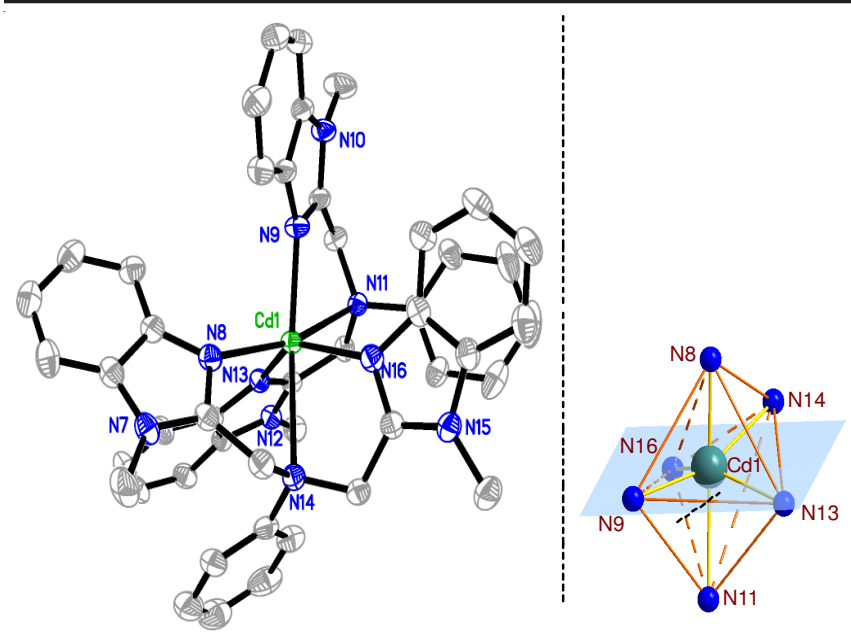

Fig. 1.. Molecular structure and atom-numberings of $\left[\mathrm{Cd}(\mathrm{Mebba})_{2}\right]^{2+}$ with hydrogen atoms omitted for clarity

The bands are shifted by around $30 \mathrm{~cm}^{-1}$ in the complex, which implies direct coordination of the metal ion to four benzimidazole nitrogen atoms and two nitrogen atoms, which are the preferred atoms for coordination as found for other metal complexes with benzimidazoles ${ }^{25}$. Information regarding the possible bonding modes of the picrate and benzimidazole rings may also be obtained from the bands ${ }^{26,27}$ at 708, 1177, 1312 and $1633 \mathrm{~cm}^{-1}$. The results agree with by X-ray diffraction data.

DMF solutions of the ligand Mebba and its cadmium(II) complex show, as expected, almost identical UV spectra. The UV bands of Mebba (284 nm) are only marginally blue-shifted $(5 \mathrm{~nm})$ in the complex, which is a clear evidence of $\mathrm{C}=\mathrm{N}$ coordination to cadmium(II). The absorption band is assigned to $\pi \rightarrow \pi^{*}$ (benzimidazole) transitions.

Hydroxyl radical scavenging activity: The hydroxyl radicals in aqueous media were generated through the Fentontype reaction ${ }^{28}$. The solution of the tested compound was prepared with DMF. The $3 \mathrm{~cm}^{3}$ reaction mixtures contained 1.0 $\mathrm{cm}^{3}$ of $0.10 \mathrm{mmol}$ aqueous safranin, $1 \mathrm{~cm}^{3}$ of $1.0 \mathrm{mmol}$ aqueous EDTA-Fe(II), $1 \mathrm{~cm}^{3}$ of $3 \%$ aqueous $\mathrm{H}_{2} \mathrm{O}_{2}$ and a series of quantitatively microadding solutions of the tested compound. The sample without the tested compound was used as the control. The reaction mixtures were incubated at $37^{\circ} \mathrm{C}$ for $60 \mathrm{~min}$ in a water-bath. Absorbance at $520 \mathrm{~nm}$ was measured and the solvent effect was corrected throughout. Hydroxyl radical bleached the safranine, so decreased absorbance of the reaction mixture indicated decreased hydroxyl radical scavenging ability ${ }^{29}$. The scavenging effect for $\mathrm{OH}^{\bullet}$ was calculated from the following expression:

$$
\text { Scavenging effect }(\%)=\frac{\left(\mathrm{A}_{\text {sample }}-\mathrm{A}_{\text {blank }}\right)}{\left(\mathrm{A}_{\text {control }}-\mathrm{A}_{\text {blank }}\right)} \times 100
$$

where $\mathrm{A}_{\text {sample }}$ is the absorbance of the sample in the presence of the tested compound, $\mathrm{A}_{\text {blank }}$ is the absorbance of the blank in the absence of the tested compound and $A_{\text {control }}$ is the absorbance in the absence of the tested compound and EDTA$\mathrm{Fe}(\mathrm{II})^{30,31}$. The $\mathrm{IC}_{50}$ values for the complexes were determined by plotting the graph of percentage inhibition of hydroxyl radical reduction against the increase in the concentration of the complex. The concentration of the complex which causes
$50 \%$ inhibition of hydroxyl radical reduction is reported as $\mathrm{IC}_{50}$. Mannitol is a well-known natural antioxidant, so we also studied the scavenging activity of mannitol against hydroxyl radical using the same mode ${ }^{32}$. Fig. 2 showed that the hydroxyl radical scavenging effects of $\mathrm{Cd}(\mathrm{II})$ complexes are much higher than the ligand Mebba, possibly in that the larger conjugated metal complexes can react with $\mathrm{OH}^{\bullet}$ to form larger stable macromolecular radicals than ligands ${ }^{33}$. The values of $\mathrm{IC}_{50}$ of $\mathrm{Cd}(\mathrm{II})$ complex for $\mathrm{OH}^{*}$ is $64 \mu \mathrm{M}$ and the values of $\mathrm{IC}_{50}$ of the ligand Mebba is $84 \mu \mathrm{M}$, while the values of $\mathrm{IC}_{50}$ of mannitol is $9.6 \mathrm{mM}^{34}$. So the hydroxyl radicals ability of all the compounds follows the order: Cd(II) complex > Mebba $>$ mannitol. It was believed that the information obtained from present work would be useful to develop new potential antioxidants and therapeutic agents for some diseases.

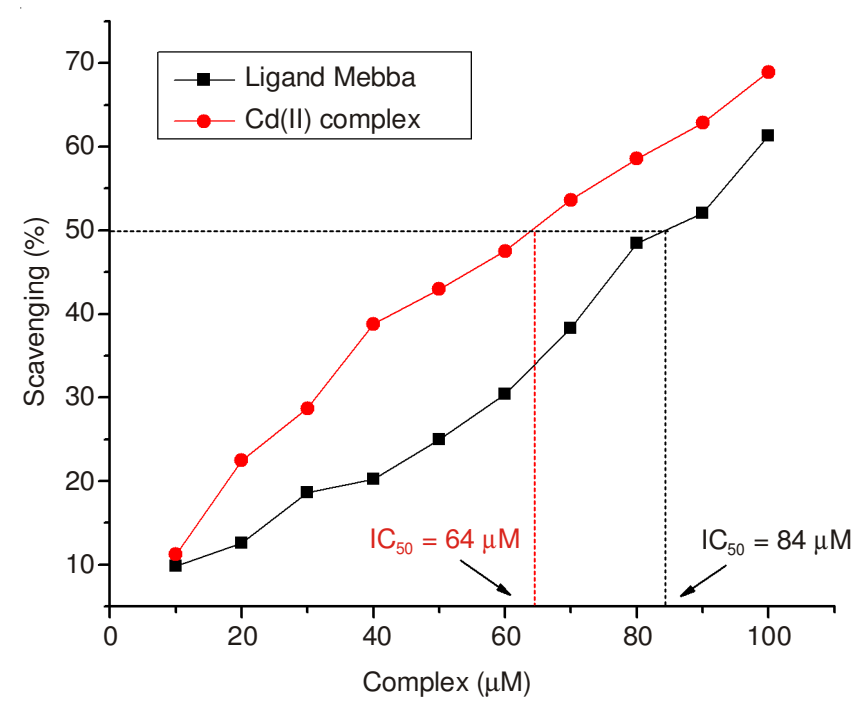

Fig. 2. Plots of $\mathrm{OH}^{\bullet}$ scavenging effect (\%) for ligands Mebba and Cd(II) complex

\section{Conclusions}

In summary, a complex $\left[\mathrm{Cd}(\mathrm{Mebba})_{2}\right](\text { pic })_{2}$ has been synthesized and characterized by elemental analysis, molar conductivity, ${ }^{1} \mathrm{H}$ NMR, IR spectra and UV-visible spectra. The structure and geometry of the $\mathrm{Cd}(\mathrm{II})$ complex was analyzed through single crystal X-ray diffraction revealed a relatively distorted coordination octahedron around $\mathrm{Cd}(\mathrm{II})$. In addition, The ligand Mebba and Cd(II) complexes have scavenging effects for hydroxyl radicals and complex shows stronger scavenging effects for hydroxyl radicals. Our research should be valuable for seeking and designing new antitumor drug and antioxidants.

\section{ACKNOWLEDGEMENTS}

The present research was supported by the National Natural Science Foundation of China (Grant No. 21367017), the Fundamental Research Funds for the Gansu Province Universities (212086), National Natural Science Foundation of Gansu Province (Grant No. 1212RJZA037) and 'Qing Lan' Talent Engineering Funds for Lanzhou Jiaotong University. 


\section{REFERENCES}

1. J.K. Barton, Science, 233, 727 (1986)

2. J. Velik, V. Baliharova, J. Fink-Gremmels, S. Bull, J. Lamka and L. Skalova, Res. Vet. Sci., 76, 95 (2004).

3. M. Devereux, D. O Shea, A. Kellett, M. McCann, M. Walsh, D. Egan, C. Deegan, K. Kedziora, G. Rosair and H. Müller-Bunz, J. Inorg. Biochem., 101, 881 (2007).

4. B.M. Zeglis, V.C. Pierre and J.K. Barton, Chem. Commun., 4565 (2007).

5. Z.C. Zhao, D.O. Arnaiz, B. Griedel, S. Sakata, J.L. Dallas, M. Whitlow, L. Trinh, J. Post, A. Liang, M.M. Morrissey and K.J. Shaw, J. Bioorg. Med. Chem. Lett., 10, 963 (2000).

6. A.H. El-Masry, H.H. Fahmy and S.H. Ali Abdelwahed, Molecules, 5, 1429 (2000).

7. P.G. Baraldi, A. Bovero, F. Fruttarolo, D. Preti, M.A. Tabrizi, M.G. Pavani and R. Romagnoli, Med. Res. Rev., 24, 475 (2004).

8. S. Demirayak, U. Abu Mohsen and A. Cagri Karaburun, Eur. J. Med. Chem., 37, 255 (2002).

9. J.-M. Shin, Y.-M. Cho and J. Sachs, J. Am. Chem. Soc., 126, 7800 (2004).

10. M. Hranjec, K. Starcevic, I. Piantanida, M. Kralj, M. Marjanovic, M. Hasani, G. Westman and G. Karminski-Zamola, Eur. J. Med. Chem., 43, 2877 (2008).

11. Z. Ates-Alagoz, S. Yildiz and E. Buyukbingol, Chemotherapy, 53, 110 (2007).

12. H. Göker, S. Özden, S. Yildiz and D.W. Boykin, Eur. J. Med. Chem., 40, 1062 (2005)

13. H. Göker, C. Kus, D.W. Boykin, S. Yildiz and N. Altanlar, Bioorg. Med. Chem., 10, 2589 (2002).

14. K. Starcevic, M. Kralj, K. Ester, I. Sabol, M. Grce, K. Pavelic and G. Karminski-Zamola, Bioorg. Med. Chem., 15, 4419 (2007).

15. H.L. Wu, B. Liu, F. Kou, F. Jia, J.K. Yuan and Y. Bai, Z. Anorg. Allg. Chem., 638, 122 (2012).

16. Bruker, APEX2 and SAINT. Bruker AXS Inc., Madison, Wisconsin, USA (2007).
17. G.M. Sheldrick, SHELXTL, Siemmens Analytical X-Ray Instruments, Inc., Madison, Wisconsin, USA (1996).

18. W.J. Geary, Coord. Chem. Rev., 7, 81 (1971).

19. T. Pandiyan, S. Bernes and C. Duran de Bazua, Polyhedron, 16, 2819 (1997).

20. T. Pandiyan, J.G. Hernández, N.T. Medina and S. Bernés, Inorg. Chim. Acta, 357, 2570 (2004).

21. J.P. Wikstrom, A.S. Filatov, R.J. Staples, C.R. Guifarro and E.V. RybakAkimova, Inorg. Chim. Acta, 363, 884 (2010).

22. M. Velusamy, M. Palaniandavar and K.R. Justin Thomas, Polyhedron, 17, 2179 (1998).

23. W.J. Zhang, W.H. Sun, S. Zhang, J.X. Hou, K. Wedeking, S. Schultz, R. Frohlich and H.B. Song, Organometallics, 25, 1961 (2006).

24. Y.-L. Guo, W. Dou, Y.-W. Wang, W.-S. Liu and D.-Q. Wang Polyhedron, 26, 1699 (2007).

25. H.L. Wu, X.C. Huang, J.K. Yuan, K. Li, J. Ding, R.R. Yun, W.K. Dong and X.Y. Fan, J. Coord. Chem., 62, 3446 (2009).

26. H.L. Wu, K.T. Wang, F. Jia, B. Liu, F. Kou, J.K. Yuan and J. Kong, J. Coord. Chem., 63, 4113 (2010)

27. H.L. Wu, R.R. Yun, K.T. Wang, K. Li, X.C. Huang, T. Sun and Y.-Y. Wang, J. Coord. Chem., 63, 243 (2010).

28. C.C. Winterbourn, J. Clin. Invest., 78, 545 (1986).

29. H. Yu, X. Liu, R. Xing, S. Liu, C. Li and P. Li, Bioorg. Med. Chem. Lett., 15, 2659 (2005).

30. B.D. Wang, Z.Y. Yang, P. Crewdson and D.- Wang, J. Inorg. Biochem., 101, 1492 (2007)

31. Z.Y. Guo, R. Xing, S. Liu, H. Yu, P. Wang, C. Li and P. Li, Bioorg. Med. Chem. Lett., 15, 4600 (2005).

32. S. Satyanarayana, J.C. Dabrowiak and J.B. Chaires, Biochemistry, 32, 2573 (1993).

33. T.R. Li, Z.Y. Yang, B.D. Wang and D.D. Qin, Eur. J. Med. Chem., 43, 1688 (2008)

34. J.I. Ueda, N. Saito, Y. Shimazu and T. Ozawa, Arch. Biochem. Biophys., 333, 377 (1996). 